\title{
Cochlearia cochlearioides (Brassicaceae) is a Rorippa
}

\author{
Ihsan A. Al-Shehbaz \\ Missouri Botanical Garden, P.O. Box 299, St. Louis, Missouri 63166-0299, U.S.A.
}

\section{Bengt Jonsell}

Bergius Botanic Garden, P.O. Box 50017, S-104 05 Stockholm, Sweden

Abstract. The Indian endemic Cochlearia cochlearioides, initially described as an Alyssum, is transferred to Rorippa, and the new combination $R$. cochlearioides (Roth) Al-Shehbaz \& Jonsell is proposed.

Rorippa cochlearioides (Roth) Al-Shehbaz \& Jonsell is endemic to India. It has been known under different names in Cochlearia L. and first appeared as C. flava in Roxburgh (1814), but that name remained a nomen nudum until it was validated by Hooker (1852). The species was validly published by Roth (1821) as Alyssum cochlearioides, a legitimate name that was placed in synonymy of the later published and illegitimate $C$. alyssoides (De Candolle, 1824). Alyssum cochlearioides was then transferred to the monotypic Trochiscus by Schulz (1933) and to Cochlearia by Maheshwari (1957), but it is evident that neither of these generic assignments is appropriate.

Perhaps the main reason that Rorippa cochlearioides has been kept for so long in Cochlearia is that it has globose, many-seeded fruits. However, such fruits are found in several species of Rorippa Scopoli, including the Asian $R$. globosa (Turczaninow ex Fischer \& C. A. Meyer) Hayek, the North American $R$. calycina (Engelmann) Rydberg, $R$. columbiae (Suksdorf ex Robinson) Suksdorf ex T. J. Howell, $R$. sphaerocarpa (A. Gray) Britton, and $R$. subumbellata Rollins, and the eastern Asian-North American $R$. barbariifolia (DC.) Kitagawa (Jonsell, 1971, 1973; Rollins, 1993).

Plants of Rorippa cochlearioides grow in lowland, tropical and subtropical areas of India and are restricted to the Gujarat and Gangetic Plains (Bhaumik, 1993). The species has pinnatifid, nonfleshy, auriculate cauline leaves, yellow flowers, spreading floral parts, terete fruits, obscurely veined thin valves, and up to 80 reddish, reticulate seeds per fruit. This combination of characters is found in many species of Rorippa and does not occur in any species of Cochlearia. Species of Cochlearia are distributed in the arctic, subarctic, and northern latitudes of the north temperate region, and they have more or less fleshy, entire to dentate nonauriculate leaves, white flowers, erect petals and stamens, somewhat narrowly septate fruits, prominently l-veined thick valves, and often few to several, often tuberculate seeds per fruit. In fact, all the Himalayan species previously assigned to Cochlearia have been or should be transferred to other genera.

It is interesting to note that Schulz (1936) placed Rorippa cochlearioides (as Trochiscus) in the tribe Drabeae, a tribe that he separated from the Arabideae primarily on the basis of silicles versus siliques, although he indicated that Nasturtium R. Brown (including Rorippa) is an exception in the Arabideae because it often has silicles. By contrast, Bhaumik (1993) placed the species (as C. cochlearioides) in the Lepidieae, where Cochlearia has been traditionally placed. In our opinion, neither of these tribal dispositions of Rorippa cochlearioides reflects its phylogenetic relationships, and the species should be placed in the same tribe as Rorippa and Nasturtium. To accommodate the species in Rorippa, the following new combination is proposed.

Rorippa cochlearioides (Roth) Al-Shehbaz \& Jonsell, comb. nov. Basionym: Alyssum cochlearioides Roth, Nov. Pl. Sp. 322. 1821. TYPE: India. Benjamin Heyne s.n. (holotype, B-W).

Literature Cited

Bhaumik, G. H. 1993. Lepidieae. In: B. D. Sharma \& N. P. Balakrishnan (editors), Fl. India 2: 188-214.

Candolle, A. P. De. 1824. Prodromus Systematis Naturalis Regni Vegetabilis, sive enumeratio contracta ordinum generum specierumque plantarum hucusque cognitarum, juxta methodi narualis normas digesta. Vol. 1. Treuttel et Würtz, Paris.

Hooker, W. J. 1852. Cochlearia flava Buch. Icon. Pl. 9: t. 805.

Jonsell, B. 1971. The genus Rorippa (Cruciferae) in eastern Siberia and the Soviet Far East. Svensk Bot. Tidskr. 65: 293-307. 
1973. Taxonomy and distribution of Rorippa (Cruciferae) in the southern U.S.S.R. Svensk Bot. Tidskr. 67: 281-302.

Maheshwari, J. K. 1957. Some changes in the Flora of India. J. Bombay Nat. Hist. Soc. 54: 804-805.

Rollins, R. C. 1993. The Cruciferae of Continental North America. Stanford Univ. Press, Stanford.

Roth, A. W. 1821. Novae Plantarum species praesertim Indiae orientalis. Ex collectione Doct. Benj. Heynii cum descriptionibus et observationibus. Halberstadii.
Roxburgh, W. 1814. Hortus Bengalensis, or a Catalogue of the Plants Growing in the Honourable East India Company's Botanic Garden at Calcutta. Mission Press, Serampore.

Schulz, O. E. 1933. Kurze Notizen über neue Gattungen, Sektionen und Arten der Cruciferen. Bot. Jahrb. Syst. 66: 91-102.

1936. Cruciferae. In: A. Engler \& K. Prantl (editors), Nat. Pflanzenfam., ed. 2., 17B: 227-658. Verlag von Wilhelm Engelmann, Leipzig. 


\section{$2 \mathrm{BHL}$ Biodiversity Heritage Library}

Al-Shehbaz, Ihsan A. and Jonsell, Bengt. 2000. "Cochlearia cochlearioides (Brassicaceae) Is a Rorippa." Novon a journal of botanical nomenclature from the Missouri Botanical Garden 10, 344-345. https://doi.org/10.2307/3392981.

View This Item Online: https://www.biodiversitylibrary.org/item/14670

DOI: https://doi.org/10.2307/3392981

Permalink: https://www.biodiversitylibrary.org/partpdf/122108

\section{Holding Institution}

Missouri Botanical Garden, Peter H. Raven Library

\section{Sponsored by}

Missouri Botanical Garden

\section{Copyright \& Reuse}

Copyright Status: In copyright. Digitized with the permission of the rights holder.

License: http://creativecommons.org/licenses/by-nc-sa/3.0/

Rights: https://biodiversitylibrary.org/permissions

This document was created from content at the Biodiversity Heritage Library, the world's largest open access digital library for biodiversity literature and archives. Visit BHL at https://www.biodiversitylibrary.org. 